\title{
Genomic NGFB variation and multiple sclerosis in a case control study
}

\author{
Denis A Akkad ${ }^{1,2}$, Niels Kruse ${ }^{3}$, Larissa Arning1, Ralf Gold ${ }^{2,4}$ and \\ Jörg T Epplen*1,2
}

Address: ${ }^{1}$ Department of Human Genetics, Ruhr-University, 44780 Bochum, Germany, ${ }^{2}$ IGSN, International Graduated School of Neuroscience, Ruhr-University, 44780 Bochum, Germany, ${ }^{3}$ Institute for Multiple Sclerosis Research, University of Goettingen and Gemeinnuetzige HertieStiftung, 37073 Goettingen, Germany and ${ }^{4}$ Department of Neurology, St. Josef-Hospital, Ruhr-University, 44791 Bochum, Germany

Email: Denis A Akkad - Amer.Akkad@rub.de; Niels Kruse -n.kruse@med.uni-goettingen.de; Larissa Arning - larissa.arning@ruhr-unibochum.de; Ralf Gold - ralf.gold@ruhr-uni-bochum.de; Jörg T Epplen* - joerg.t.epplen@ruhr-uni-bochum.de

* Corresponding author

Published: 8 December 2008

BMC Medical Genetics 2008, 9:107 doi:10.1186/147I-2350-9-107
Received: 6 August 2008

Accepted: 8 December 2008

This article is available from: http://www.biomedcentral.com/I47I-2350/9//07

(c) 2008 Akkad et al; licensee BioMed Central Ltd.

This is an Open Access article distributed under the terms of the Creative Commons Attribution License (http://creativecommons.org/licenses/by/2.0), which permits unrestricted use, distribution, and reproduction in any medium, provided the original work is properly cited.

\begin{abstract}
Background: Nerve growth factor $\beta$ (NGFB) is involved in cell proliferation and survival, and it is a mediator of the immune response. ProNGF, the precursor protein of NGFB, has been shown to induce cell death via interaction with the p75 neurotrophin receptor. In addition, this neurotrophin is differentially expressed in males and females. Hence NGFB is a good candidate to influence the course of multiple sclerosis (MS), much like in the murine model of experimental autoimmune encephalomyelitis (EAE).

Methods: Ten single nucleotide polymorphisms (SNPs) were genotyped in the NGFB gene in up to I 120 unrelated MS patients and 869 controls. Expression analyses were performed for selected MS patients in order to elucidate the possible functional relevance of the SNPs.
\end{abstract}

Results: Significant association of NGFB variations with MS is evident for two SNPs. NGFB mRNA seems to be expressed in sex- and disease progression-related manner in peripheral blood mononuclear cells.

Conclusion: NGFB variation and expression levels appear as modulating factors in the development of MS.

\section{Background}

Multiple sclerosis (MS) was shown to depend on genetic components in various twin-, family- and association based studies[1]. This common neuro-inflammatory disease with neurodegenerative aspects leads to demyelination in the central nervous system (CNS)[1]. Complex interplays of environment and genetic factors are likely causes for disease development[2]. Yet, it is not entirely clear why females are usually affected more frequently than men. In different populations the only virtually consistent MS susceptibility factor is comprised in the HLADRB1 region. Recent studies point to complex allelic interactions of the HLA-DRB1 locus[3] underscoring possible (auto-) immune mechanisms in the pathogenesis of MS. Genetic factors determining susceptibility/disease progression are only incompletely understood, among which neurotrophins may be relevant like e.g. ciliary neurotrophic factors. 
Here, we focussed on the nerve growth factor beta (NGFB) gene known to be involved in many cell regulatory pathways including cell survival and proliferation as well as in immune regulatory processes[4]. Analyses of NGFB in rodents[5] as well as in humans[6] show sex specific differences in secretion levels of the protein, whereby females have generally lower NGFB protein levels than males. In addition to crucial involvement in neuro-regulatory aspects of NGFB, the gene is located on chromosome 1p13.1, a region reported to be associated with MS, as revealed by admixture mapping[7]. NGFB has also been shown to delay the onset of clinical experimental autoimmune encephalomyelitis (EAE) as well as to prevent full development of EAE lesions[8]. Furthermore, anti-NGF mice reveal a progressive neurodegenerative phenotype[9]. Thus, altogether, NGFB is a prominent candidate gene to influence MS development.

\section{Methods \\ Samples}

DNA samples were genotyped from 1120 unrelated MS patients ( 372 males with $31.7 \pm 9.8$ years at age of onset and 748 females with $31.5 \pm 10.0$ years at age of onset), 622 of which showed relapsing remitting (rr), $252 \mathrm{sec}-$ ondary progressive (sp) and 249 primary progressive (pp) course according to the Poser criteria as well as 869 healthy blood donors ( 444 males, $47.9 \pm 13$. 8 years of age and 425 females, $48.5 \pm 16.1$ years of age) resided in the Rhein-Ruhr area (Germany) as detailed in previous studies[10]. Informed consent has been obtained from all patients and controls. Research on human DNA for MS was approved by the ethics commission of the medical faculty of the Ruhr-University Bochum, Germany.

\section{Genotyping}

Genotyping was performed via polymerase chain reaction (PCR) with subsequent restriction fragment length polymorphism (RFLP) analyses or via TaqMan ${ }^{\circledR}$ assays (see additional file 1 , table 3 for detailed information). Statistical analyses were done by $\chi^{2}$ testing with a Bonferroni corrected statistical significance level. Hardy-Weinberg equilibrium was evaluated using Pearson's goodness-of-fit chi-square test (degree of freedom $=1$ ). Power analyses for this study were performed using GPower software assuming small effect size of 0.20 of the variation, $\alpha=0.05$ and degree of freedom $(D F)=2$ (data not shown)[11].

\section{Expression analyses}

Fresh peripheral blood mononuclear cells (PBMCs) were obtained from MS patients in stable phases of the disease. $66 \%$ of patients received immunomodulatory treatment (Copaxone, MX, Betaferon and Cortison). RNA of 23 male patients (of which eight suffered from rr (three $\varnothing$ treatment), eleven from sp (three $\varnothing$ treatment) and four from pp MS (one $\varnothing$ treatment)) as well as ten females (of which five showed $\operatorname{rr}$ (two $\varnothing$ treatment) and five sp (two $\varnothing$ treatment) MS course) was isolated using the RNeasy kit (Qiagen). Expression analyses were performed using QuantiTect $^{\circledast}$ SYBR $^{\circledast}$ Green one-step RT-PCR (Qiagen). The quantification of NGFB RNA was analysed using the $\Delta \Delta \mathrm{Ct}$ method. Oligonucleotides used were F-GCT TTC TAT CCT GGC CAC A, R-CAG GGA CAT TGC TCT CTG AG for the analysed NGFB as well as F-AGG TCG GAG TCA ACG GAT TTG, R-AAG CAG CCC TGG TGA CCA G for GAPDH as reference system. Statistical analyses were performed using t-tests (statistical program for the social sciences; SPSS).

\section{Results}

We report genotyping data of ten SNPs covering the coding region of the NGFB gene with subsequent expression analysis in 23 male and ten female MS patients. A map of the genotyped SNPs in the NGFB gene is depicted in figure 1. Initial genotyping was performed for rs 6330 located in exon 3 of the NGFB gene, since this exon encodes the precursor protein proNGF exclusively. rs6330 showed significant association in allele $(\mathrm{p}=0.0038 ; \mathrm{OR}=1.210$ $(1.063-1.377))$ and genotype frequencies $(p=0.0126)$ when comparing healthy controls and MS patients. Interestingly, the strongest association was observed mainly for male rr MS patients for allele $(\mathrm{p}=0.0087$; OR $=1.386$ $(1.086-1.770))$ and genotype frequencies $(\mathrm{p}=0.0230)$ when stratifying the cohorts by sex and disease progression, although the $\mathrm{C}$ allele was in general increased in all

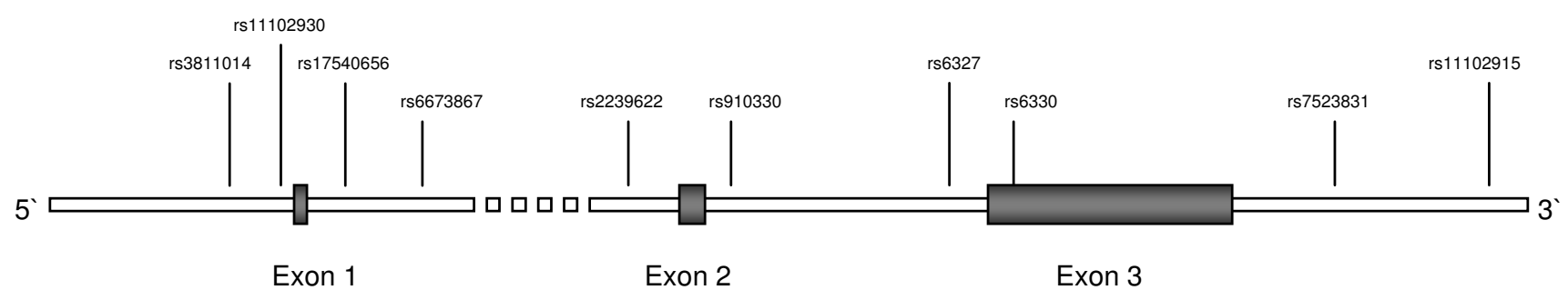

Figure I

Schematic representation of the NGFB gene structure and the location of the genotyped SNPs. 
Table I: Detailed analysis for rs6330, genotyped in I I 20 and 869 controls.

\begin{tabular}{|c|c|c|c|c|c|c|c|c|c|c|c|c|c|c|c|}
\hline \multirow[b]{2}{*}{$\begin{array}{c}\text { SNP } \\
\text { (maj./min. } \\
\text { allele) }\end{array}$} & \multirow[b]{2}{*}{ cohort } & \multirow[b]{2}{*}{$\begin{array}{l}\text { Stratif- } \\
\text { ication }\end{array}$} & \multirow[b]{2}{*}{$\begin{array}{l}\text { Maj. allele } \\
(\%)\end{array}$} & \multirow[b]{2}{*}{$\begin{array}{l}\text { Min. allele } \\
(\%)\end{array}$} & \multirow[b]{2}{*}{$P$ value } & \multirow[b]{2}{*}{ OR $\left(\mathrm{Cl}^{* 1}\right)$} & \multicolumn{4}{|c|}{ Genotype (\%) } & \multicolumn{5}{|c|}{$P$ value } \\
\hline & & & & & & & $x x$ & $X x$ & $x x$ & $\begin{array}{l}\text { Geno- } \\
\text { type }\end{array}$ & $\begin{array}{c}\text { Major allel } \\
\text { dominant }\end{array}$ & $\begin{array}{c}\text { co- } \\
\text { dominant }\end{array}$ & $\begin{array}{l}\text { Minor } \\
\text { allele } \\
\text { dominant }\end{array}$ & $\begin{array}{l}\text { HWE } p \\
\text { value }\end{array}$ & $\mathrm{N}$ \\
\hline \multirow[t]{15}{*}{$\begin{array}{c}\text { rs6330 } \\
(\mathrm{C} / \mathrm{T})\end{array}$} & MS & $\varnothing$ & $\begin{array}{r}1235 \\
(57.2)\end{array}$ & $\begin{array}{c}923 \\
(42.8)\end{array}$ & 0.0038 & $\begin{array}{c}1.210 \\
(1.063- \\
1.377)\end{array}$ & $\begin{array}{c}356 \\
(33.0)\end{array}$ & $\begin{array}{c}523 \\
(48.5)\end{array}$ & $\begin{array}{c}200 \\
(18.5)\end{array}$ & 0.0126 & 0.0579 & 0.3034 & 0.0056 & 0.75 & 1079 \\
\hline & & male & $\begin{array}{c}438 \\
(59.8)\end{array}$ & $\begin{array}{c}294 \\
(40.2)\end{array}$ & 0.0087 & $\begin{array}{c}1.308 \\
(1.070- \\
1.599)\end{array}$ & $\begin{array}{c}133 \\
(36.3)\end{array}$ & $\begin{array}{c}172 \\
(47.0)\end{array}$ & 61 (16.7) & 0.0247 & 0.1109 & 0.2403 & 0.0091 & 0.67 & 366 \\
\hline & & female & $\begin{array}{c}797 \\
(55.9)\end{array}$ & $\begin{array}{c}629 \\
(44.1)\end{array}$ & 0.0598 & $\begin{array}{c}1.149 \\
(0.946- \\
1.395)\end{array}$ & $\begin{array}{c}223 \\
(31.3)\end{array}$ & $\begin{array}{c}351 \\
(49.2)\end{array}$ & $\begin{array}{c}139 \\
(19.5)\end{array}$ & 0.1672 & 0.1665 & 0.6840 & 0.0938 & 0.97 & 713 \\
\hline & & $\operatorname{rr} \varnothing$ & $\begin{array}{c}677 \\
(56.9)\end{array}$ & $\begin{array}{c}513 \\
(43.1)\end{array}$ & 0.0211 & $\begin{array}{c}1.193 \\
(1.015- \\
1.210)\end{array}$ & $\begin{array}{c}192 \\
(32.3)\end{array}$ & $\begin{array}{c}293 \\
(49.2)\end{array}$ & $\begin{array}{c}110 \\
(18.5)\end{array}$ & 0.0647 & 0.1011 & 0.5493 & 0.0345 & 0.92 & 595 \\
\hline & & $\mathrm{rr}$ male & $\begin{array}{c}240 \\
(61.2)\end{array}$ & $\begin{array}{c}152 \\
(38.8)\end{array}$ & 0.0087 & $\begin{array}{c}1.386 \\
(1.086- \\
1.770)\end{array}$ & $75(38.3)$ & $90(45.9)$ & $31(15.8)$ & 0.0230 & 0.1196 & 0.2226 & 0.0081 & 0.65 & 196 \\
\hline & & rr female & $\begin{array}{c}437 \\
(54.8)\end{array}$ & $\begin{array}{c}361 \\
(45.2)\end{array}$ & 0.2276 & $\begin{array}{c}1.098 \\
(0.885- \\
1.361)\end{array}$ & $\begin{array}{c}117 \\
(29.3)\end{array}$ & $\begin{array}{c}203 \\
(50.9)\end{array}$ & 79 (19.8) & 0.4648 & 0.2701 & 0.9151 & 0.3737 & 0.59 & 399 \\
\hline & & sp $\varnothing$ & $\begin{array}{c}27 I \\
(56.5)\end{array}$ & $\begin{array}{c}209 \\
(43.5)\end{array}$ & 0.1276 & $\begin{array}{c}1.173 \\
(0.955- \\
1.439)\end{array}$ & $78(32.5)$ & $\begin{array}{c}115 \\
(47.9)\end{array}$ & 47 (19.6) & 0.2503 & 0.4119 & 0.4231 & 0.1016 & 0.69 & 240 \\
\hline & & sp male & $73(55.3)$ & $59(44.7)$ & 0.6597 & $\begin{array}{c}1.086 \\
(0.752- \\
1.569)\end{array}$ & $21(31.8)$ & $31(47.0)$ & 14 (21.2) & 0.7583 & 0.9914 & 0.5229 & 0.4839 & 0.69 & 66 \\
\hline & & sp female & $\begin{array}{c}198 \\
(56.9)\end{array}$ & $\begin{array}{c}150 \\
(43.1)\end{array}$ & 0.1082 & $\begin{array}{c}1.197 \\
(0.915- \\
1.565)\end{array}$ & $57(32.8)$ & $84(48.3)$ & $33(19.0)$ & 0.2593 & 0.2818 & 0.6243 & 0.1264 & 0.84 & 174 \\
\hline & & $\mathrm{Pp} \varnothing$ & $\begin{array}{c}287 \\
(58.8)\end{array}$ & $\begin{array}{c}201 \\
(41.2)\end{array}$ & 0.0143 & $\begin{array}{c}1.291 \\
(1.052- \\
1.584)\end{array}$ & $86(35.2)$ & $\begin{array}{c}115 \\
(47.1)\end{array}$ & $43(17.6)$ & 0.0369 & 0.1358 & 0.3070 & 0.0137 & 0.67 & 244 \\
\hline & & Pp male & $\begin{array}{c}125 \\
(60.1)\end{array}$ & $83(39.9)$ & 0.0759 & $\begin{array}{c}1.322 \\
(0.97 I- \\
1.800)\end{array}$ & $37(35.6)$ & $51(49.0)$ & $16(15.4)$ & 0.1967 & 0.1883 & 0.6930 & 0.1116 & 0.82 & 104 \\
\hline & & Pp female & $\begin{array}{c}162 \\
(57.9)\end{array}$ & $\begin{array}{c}118 \\
(42.1)\end{array}$ & 0.0779 & $\begin{array}{c}1.245 \\
(0.933- \\
1.660)\end{array}$ & $49(35.0)$ & 64 (45.7) & 27 (19.3) & 0.1540 & 0.3615 & 0.3297 & 0.0557 & 0.46 & 140 \\
\hline & control & $\varnothing$ & $\begin{array}{c}857 \\
(52.5)\end{array}$ & $\begin{array}{c}775 \\
(47.5)\end{array}$ & & & $\begin{array}{c}221 \\
(27.1)\end{array}$ & $\begin{array}{c}415 \\
(50.9)\end{array}$ & $\begin{array}{c}180 \\
(22.1)\end{array}$ & & & & & 0.57 & 816 \\
\hline & & male & $\begin{array}{c}443 \\
(53.2)\end{array}$ & $\begin{array}{c}389 \\
(46.8)\end{array}$ & & & $\begin{array}{l}115 \\
(27.6)\end{array}$ & $\begin{array}{c}213 \\
(51.2)\end{array}$ & $88(21.2)$ & & & & & 0.56 & 416 \\
\hline & & female & $\begin{array}{c}414 \\
(51.7)\end{array}$ & $\begin{array}{c}386 \\
(48.3)\end{array}$ & & & $\begin{array}{c}106 \\
(26.5)\end{array}$ & $\begin{array}{c}202 \\
(50.5)\end{array}$ & $92(23.0)$ & & & & & 0.82 & 400 \\
\hline
\end{tabular}


MS sub-cohorts (see table 1). Subsequent genotyping of three flanking SNPs (rs6327, rs7523831 and rs11102915) in subgroups of our cohorts of 263 rr MS patients and 259 controls showed no additional significant association (see additional file 1, table 4), thus restricting the region of interest. Further SNP genotyping in the vicinity of exons 1 and 2 was performed in order to clarify putative importance of these non-protein coding regions. No significant association was found for SNPs rs2239622 and rs910330 flanking exon 2 in the subgroups of our cohorts (see additional file 1, table 4).

A tendency for MS association of the promoter SNP rs11102930 was observed for the co-dominant transmission model for the subgroup of $263 \mathrm{rr}$ MS patients as compared to healthy controls (see additional file 1, table 4). Gender stratification showed, despite of decreased power, significant association of rs 11102930 in male MS patients compared to male controls for the co-dominant transmission model (data not shown). Female MS patients did not show conspicuous differences when compared to healthy female controls. Analyses of three flanking SNPs, rs3811014, rs17540656 and rs6673867 in the defined subgroups showed no significant association for male MS patients compared to healthy male controls as well as no significant association between female MS patients and female controls, respectively (data not shown). The conspicuous tendency of sex-specific association of rs11102930 SNP in male MS patients was confirmed when additionally the remaining individuals were genotyped (860 unrelated MS patients and 611 controls, $\mathrm{p}=$ $0.0115 ; \mathrm{OR}=0.765(0.622-0.942))$. Further stratification of all tested MS patients for disease progression indicates despite the small male rr MS cohort size $(n=179)$ that the significant association is eventually based on the difference in allele $(\mathrm{p}=0.0101 ; \mathrm{OR}=0.717(0.557-0.924))$ and genotype $(\mathrm{p}=0.0206)$ frequency distributions of male rr MS patients compared to healthy male controls (see table 2).

23 male MS patients were characterized via quantitative RT-PCR after selection for opposite homozygosity in rs11102930: No correlation was observed between genotypes and expression levels. Yet, correlating with disease progression reveals significant differences in NGFB RNA expression levels between $\mathrm{rr}$ and sp/pp MS patients, respectively $(p=0.003$; see figure 2$)$. We evaluated the NGFB expression levels in correlation with disease course also in females, although no differences were observed in the allele and genotype frequencies for rs11102930. Five female patients with rr MS were compared to five female patients with sp course, both harboring the more frequent homozygous genotype for rs11102930. The two groups showed no tendencies for different expression profiles.
Influence of MS treatment on the observed expression data was not evident.

\section{Discussion}

NGFB as well as its precursor protein proNGF have been shown to be involved in several crucial processes relating to MS pathogenesis. NGFB itself, in addition to its important role as modulatory mediator of the immune response[12], initiates and maintains cell proliferation and survival. In contrast, proNGF has been shown to induce cell death via interaction with the p75 neurotrophin receptor[13]. Here we present genotyping data of the NGFB gene for ten selected SNPs in up to 1120 unrelated MS patients and 869 controls. Of ten tested SNPs two show significant association in sex- and disease progression-specific manner, whereby rs6330 is located in exon 3 and rs11102930 in the promoter region of the NGFB gene (see figure 1). SNP rs6330 is defined as a C/T exchange leading to the non-synonymous amino acid substitution of alanine to valine in position 35 . The increase in amino acid size could modify the tertiary structure of proNGF, leading to altered interaction and signalling via the $\mathrm{p} 75$ neurotrophin receptor. Since the $\mathrm{C}$ allele is more frequent in MS patients compared to healthy controls $(57.2 \%$ vs. $52.5 \%)$, this allele could represent a risk factor due to its possible role in inducing increased cell death via enhanced interaction with the p75 neurotrophin receptor. Interestingly, male MS patients seem to have a higher risk than female MS patients (see table 1). The actual effect of the amino acid exchange on eventually altered interaction of proNGF and the p75 neurotrophin receptor has to be shown definitively in follow-up studies in order to clarify any functional relevance.

rs11102930 is located in the promoter region of the NGFB gene and has been shown via electrophoretic mobility shift assays to be functionally relevant by affecting the binding of the vitamin $\mathrm{D}$ receptor (VDR) to its DNA motif[14]. VDR has a higher binding affinity for the C than for the T allele. Interestingly, VDR variation itself has been found to be associated with MS [15] and it affects the EAE course in the mouse model[16]. For our MS cohort, we show that only male patients have a significantly increased frequency of the $\mathrm{C}$ allele $\mathrm{P}_{\text {unc }}=0.01$ and a significant effect in the $\mathrm{C}$ dominant model for the genotype distribution $p_{u n c}=0.0075$ (see table 2). Further stratification of male MS patients for rs11102930 association indicates that only male $\mathrm{rr}$ MS patients show a significantly increased frequency of the $C$ allele $p_{u n c}=0.01$. This effect has to be verified in larger male (rr) MS cohorts in order to provide convincing statistical power. Under the assumption of enhanced NGFB expression due to the higher affinity of the VDR binding in case of the $\mathrm{C}$ allele, we propose a protective effect of the $\mathrm{C}$ allele due to higher NGFB levels and its cell proliferating and survival mediat- 
Table 2: Detailed analysis for rs I I I 02930, genotyped in I I 20 and 869 controls.

\begin{tabular}{|c|c|c|c|c|c|c|c|c|c|c|c|c|c|c|c|}
\hline \multirow[b]{2}{*}{$\begin{array}{c}\text { SNP } \\
\text { (maj./min. } \\
\text { allele) }\end{array}$} & \multirow[b]{2}{*}{ cohort } & \multirow[b]{2}{*}{$\begin{array}{l}\text { Stratif- } \\
\text { ication }\end{array}$} & \multirow[b]{2}{*}{$\begin{array}{l}\text { Maj. allele } \\
\text { (\%) }\end{array}$} & \multirow[b]{2}{*}{$\begin{array}{l}\text { Min. allele } \\
\text { (\%) }\end{array}$} & \multirow[b]{2}{*}{$P$ value } & \multirow[b]{2}{*}{ OR $\left(\mathrm{Cl}^{* \mathrm{I}}\right)$} & \multicolumn{4}{|c|}{ Genotype (\%) } & \multicolumn{5}{|c|}{$P$ value } \\
\hline & & & & & & & $x x$ & $X x$ & $x x$ & $\begin{array}{l}\text { Geno- } \\
\text { type }\end{array}$ & $\begin{array}{c}\text { Major allel } \\
\text { dominant }\end{array}$ & $\begin{array}{c}\text { co- } \\
\text { dominant }\end{array}$ & $\begin{array}{c}\text { Minor } \\
\text { allele } \\
\text { dominant }\end{array}$ & $\begin{array}{l}\text { HWE } p \\
\text { value }\end{array}$ & $N$ \\
\hline \multirow[t]{15}{*}{$\begin{array}{c}\text { rs I I I } 0293 \\
0 \text { (T/C) }\end{array}$} & MS & $\varnothing$ & $\begin{array}{l}1380 \\
(64.3)\end{array}$ & $\begin{array}{c}766 \\
(35.7)\end{array}$ & 0.5414 & $\begin{array}{c}0.959 \\
(0.840- \\
1.096)\end{array}$ & $\begin{array}{c}449 \\
(41.8)\end{array}$ & $\begin{array}{c}482 \\
(44.9)\end{array}$ & $\begin{array}{c}142 \\
(13.2)\end{array}$ & 0.6694 & 0.3713 & 0.7157 & 0.8148 & 0.48 & 1073 \\
\hline & & male & $\begin{array}{c}423 \\
(60.8)\end{array}$ & $\begin{array}{c}273 \\
(39.2)\end{array}$ & 0.0115 & $\begin{array}{c}0.765 \\
(0.622- \\
0.942)\end{array}$ & $\begin{array}{c}124 \\
(35.6)\end{array}$ & $\begin{array}{c}175 \\
(50.3)\end{array}$ & $49(14.1)$ & 0.0259 & 0.2272 & 0.0664 & 0.0075 & 0.31 & 348 \\
\hline & & female & $\begin{array}{c}957 \\
(66.0)\end{array}$ & $\begin{array}{c}493 \\
(34.0)\end{array}$ & 0.2271 & $\begin{array}{r}1.115 \\
(0.934- \\
1.332)\end{array}$ & $\begin{array}{c}325 \\
(44.8)\end{array}$ & $\begin{array}{c}307 \\
(42.3)\end{array}$ & $93(12.8)$ & 0.1682 & 0.8954 & 0.0695 & 0.0829 & 0.13 & 725 \\
\hline & & $\operatorname{rr} \varnothing$ & $\begin{array}{c}764 \\
(65.1)\end{array}$ & $\begin{array}{c}410 \\
(34.9)\end{array}$ & 0.9120 & $\begin{array}{c}0.991 \\
(0.848- \\
1.158)\end{array}$ & $\begin{array}{c}251 \\
(42.8)\end{array}$ & $\begin{array}{c}262 \\
(44.6)\end{array}$ & $74(12.6)$ & 0.8773 & 0.6845 & 0.7010 & 0.9061 & 0.66 & 587 \\
\hline & & rr male & $\begin{array}{c}212 \\
(59.2)\end{array}$ & $\begin{array}{c}146 \\
(40.8)\end{array}$ & 0.0101 & $\begin{array}{c}0.717 \\
(0.557- \\
0.924)\end{array}$ & $59(33.0)$ & $94(52.5)$ & $26(14.5)$ & 0.0206 & 0.2537 & 0.0465 & 0.0056 & 0.24 & 179 \\
\hline & & rr female & $\begin{array}{c}552 \\
(67.6)\end{array}$ & $\begin{array}{c}264 \\
(32.4)\end{array}$ & 0.0760 & $\begin{array}{c}1.201 \\
(0.981- \\
1.472)\end{array}$ & $\begin{array}{c}192 \\
(47.1)\end{array}$ & $\begin{array}{c}168 \\
(41.2)\end{array}$ & $48(11.8)$ & 0.0872 & 0.7263 & 0.0525 & 0.0295 & 0.23 & 408 \\
\hline & & sp $\varnothing$ & $\begin{array}{c}303 \\
(62.9)\end{array}$ & $\begin{array}{c}179 \\
(37.1)\end{array}$ & 0.3324 & $\begin{array}{c}0.901 \\
(0.731- \\
1.112)\end{array}$ & $97(40.2)$ & $\begin{array}{c}109 \\
(45.2)\end{array}$ & $35(14.5)$ & 0.5288 & 0.2712 & 0.8855 & 0.5545 & 0.63 & 241 \\
\hline & & sp male & $78(59.1)$ & $54(40.9)$ & 0.0764 & $\begin{array}{c}0.714 \\
(0.491- \\
1.036)\end{array}$ & $23(34.8)$ & $32(48.5)$ & II (16.7) & 0.2125 & 0.2026 & 0.4665 & 0.1183 & 0.98 & 66 \\
\hline & & sp female & $\begin{array}{c}225 \\
(64.3)\end{array}$ & $\begin{array}{c}125 \\
(35.7)\end{array}$ & 0.7989 & $\begin{array}{c}1.034 \\
(0.798- \\
1.341)\end{array}$ & $74(42.3)$ & $77(44.0)$ & 24 (I3.7) & 0.6875 & 0.7015 & 0.3886 & 0.5387 & 0.58 & 175 \\
\hline & & $\mathrm{PP} \varnothing$ & $\begin{array}{c}313 \\
(63.9)\end{array}$ & $\begin{array}{c}177 \\
(36.1)\end{array}$ & 0.5743 & $\begin{array}{c}0.942 \\
(0.764- \\
1.161)\end{array}$ & $\begin{array}{c}101 \\
(41.2)\end{array}$ & $\begin{array}{c}111 \\
(45.3)\end{array}$ & $33(13.5)$ & 0.7926 & 0.5014 & 0.9019 & 0.7477 & 0.77 & 245 \\
\hline & & PP male & $\begin{array}{c}133 \\
(64.6)\end{array}$ & $73(35.4)$ & 0.5167 & $\begin{array}{c}0.900 \\
(0.655- \\
1.237)\end{array}$ & $42(40.8)$ & $49(47.6)$ & $12(11.7)$ & 0.7250 & 0.8995 & 0.4775 & 0.4289 & 0.69 & 103 \\
\hline & & PP female & $\begin{array}{l}180 \\
(63.4)\end{array}$ & $\begin{array}{c}104 \\
(36.6)\end{array}$ & 0.9694 & $\begin{array}{c}0.995 \\
(0.753- \\
1.314)\end{array}$ & $59(4 \mid .5)$ & $62(43.7)$ & $21(14.8)$ & 0.6352 & 0.4961 & 0.3850 & 0.6777 & 0.48 & 142 \\
\hline & control & $\varnothing$ & $\begin{array}{l}1121 \\
(65.3)\end{array}$ & $\begin{array}{c}597 \\
(34.7)\end{array}$ & & & $\begin{array}{c}364 \\
(42.4)\end{array}$ & $\begin{array}{c}393 \\
(45.8)\end{array}$ & $\begin{array}{c}102 \\
(11.9)\end{array}$ & & & & & 0.79 & 859 \\
\hline & & male & $\begin{array}{c}585 \\
(66.9)\end{array}$ & $\begin{array}{c}289 \\
(33.1)\end{array}$ & & & $\begin{array}{c}197 \\
(45.1)\end{array}$ & $\begin{array}{c}191 \\
(43.7)\end{array}$ & $49(11.2)$ & & & & & 0.79 & 437 \\
\hline & & female & $\begin{array}{c}536 \\
(63.5)\end{array}$ & $\begin{array}{c}308 \\
(36.5)\end{array}$ & & & $\begin{array}{c}167 \\
(39.6)\end{array}$ & $\begin{array}{c}202 \\
(47.9)\end{array}$ & $53(12.6)$ & & & & & 0.50 & 422 \\
\hline
\end{tabular}




\section{NGFB expression profile in $\hat{\partial} \hat{O}$}

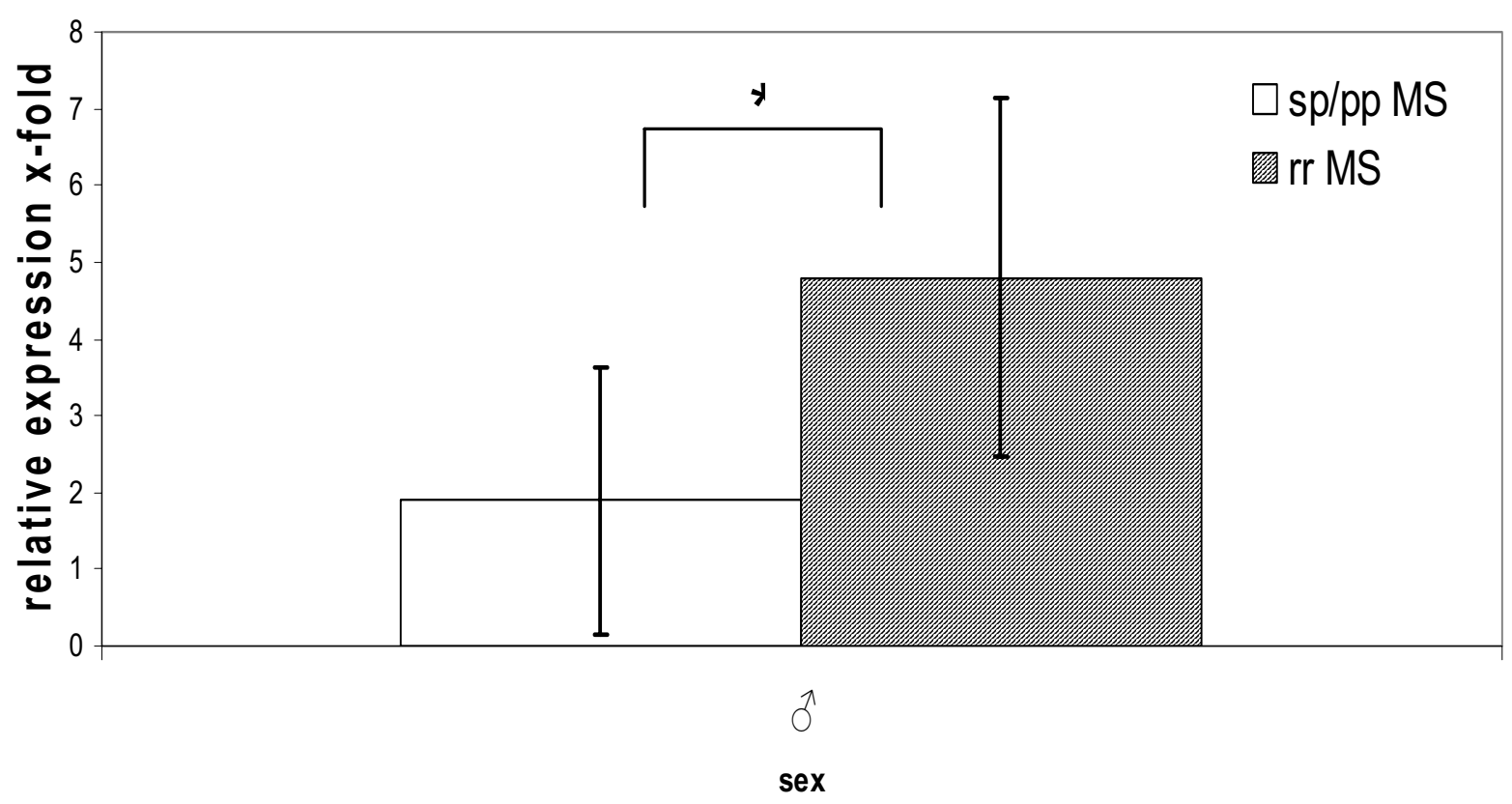

NGFB expression profile in $q+$

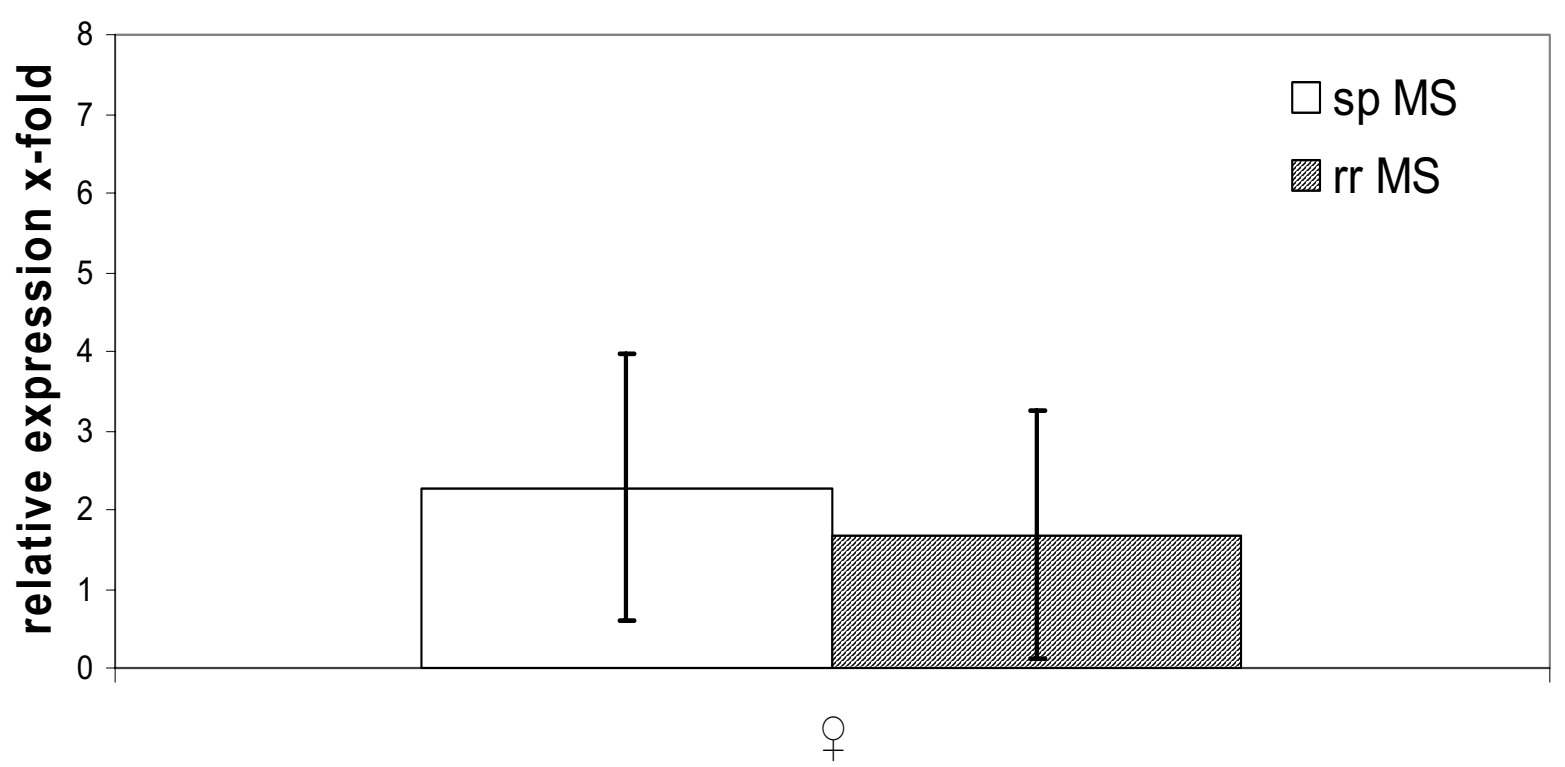

sex

Figure 2

NGFB expression profile comparison of male rr vs. sp/pp MS patients and female rr vs. sp MS patients, respectively. Significant differences are obvious between male MS patients with different course of the disease; $*_{p}=0.003$ (SPS ttest). 
ing properties, thus preventing chronic disease progression. Although rs11102930 is reported to alter the binding affinity of the VDR, the expression regulatory influence has still to be shown via in vitro reporter assays. Our analyses of the rs11102930 genotype on the expression profile revealed no correlation of the genotype patterns for SNP rs11102930 and NGFB levels. Yet, male rr MS patients have a 2.5 fold elevated expression in comparison to male $\mathrm{sp}+\mathrm{pp} \mathrm{MS}$ patients as shown in figure 2 (or only male sp MS, data not shown). Both, sp and pp MS patients were evaluated in combination because of chronic disease progression. This expression difference based on disease progression differentiation was not observed in female MS patients perhaps due to the small sample size, differences in menstruation cycle stages (no information available) or perhaps there are no differences. Comparison between female and male MS patients were not feasible since sex-specific expression differences have been described for healthy controls $[5,6]$.

Our results indicate a disease modulating role of NGFB for MS progression as shown in the EAE model[8]. The previously reported lower NGFB levels in healthy females compared to healthy males could perhaps partially explain why females are affected twice as often as males with MS based on the neuro-protective and cell proliferative stimulating properties of NGFB. Since the serum level of NGFB is low in females and, in addition, depends on the menstrual cycle phase[17], marginal modulations of NGFB expression or NGFB interactions may have no profound effects on disease progression in women. This fact could explain why no significant differences in genotype and allele frequency patterns for rs6330 and rs 11102930 were observed in the analysed female MS patients. Under this assumption we hypothesise in the case of rs6330, the $\mathrm{C}$ allele to be a risk factor for MS by eventually modulating the interaction of the proNGF with the p75 neurotrophin receptor and thus promoting cell death. In contrast the rs $11102930 \mathrm{C}$ allele located in the promoter region might provide protection for male MS patients, eventually preventing chronic disease progression due to perhaps increased NGFB expression. Which of the significantly associated SNPs are responsible for the change in expression profile of NGFB? No correlation could be drawn between the expression results and the genotype pattern. Hence, it is likely that combined effects of the tested SNPs lead to the observed results. According to our expression lower NGFB concentration in male MS patients may lead to chronic disease progression (see figure 2). Such an assertion needs to be verified independently.

The complex LD patterns for the 52.32 kilobase pair long sequence (see HapMap data) and the haplotype analysis for the 10 tested SNPs make predictions of putative interactions of rs6330 with rs11102930 largely impossible (see additional file 1, figure 3 for detailed information). Conversely, it is theoretically possible that other linked sequence variations are responsible for the observed phenomena.

\section{Conclusion}

NGFB as multifunctional protein might affect MS courses differentially as well as other neurodegenerative diseases in a complex manner. Therefore, further detailed studies appear warranted.

\section{Competing interests}

The authors declare that they have no competing interests.

\section{Authors' contributions}

DAA performed the genotyping, calculated the statistics and drafted the manuscript. NK performed the expression analyses. LA, RG and JTE participated in the design of the study, evaluated the data and finalised the manuscript which was approved by all authors in the final version.

\section{Additional material}

\section{Additional File 1}

Assay data and statistical analysis (Chi-Square, Haplotype block representation) for the 10 tested NGFB SNPs. Provided are the data for the genotyping assays of the 10 tested SNPs in the NGFB gene as well as the corresponding statistical analysis including the Haplotype block representation.

Click here for file

[http://www.biomedcentral.com/content/supplementary/1471-

2350-9-107-S1.doc]

\section{Acknowledgements}

We are grateful to the patients and controls who volunteered to participate in this study. Furthermore, we acknowledge the support of the International Graduate School of Neuroscience (IGSN).

\section{References}

I. Oksenberg JR, Barcellos LF: Multiple sclerosis genetics: leaving no stone unturned. Genes Immun 2005, 6(5):375-387.

2. Hauser SL, Oksenberg JR: The neurobiology of multiple sclerosis: genes, inflammation, and neurodegeneration. Neuron 2006, 52(I):61-76.

3. Barcellos LF, Sawcer S, Ramsay PP, Baranzini SE, Thomson G, Briggs F, Cree BC, Begovich AB, Villoslada P, Montalban X, et al.: Heterogeneity at the HLA-DRB I locus and risk for multiple sclerosis. Hum Mol Genet 2006, I 5(I8):28|3-2824.

4. Bracci-Laudiero L, Aloe L, Caroleo MC, Buanne P, Costa N, Starace G, Lundeberg T: Endogenous NGF regulates CGRP expression in human monocytes, and affects HLA-DR and CD86 expression and IL- 10 production. Blood 2005, I 06( I 0):3507-35 I4.

5. Lipps BV: Age and sex-related difference in levels of nerve growth factor in organs of Balb/c mice. J Nat Toxins 2002, II (4):387-39I.

6. Serrano T, Lorigados LC, Armenteros S: Nerve growth factor levels in normal human sera. Neuroreport 1996, 8(1): 179-181.

7. Reich D, Patterson N, De jager PL, McDonald G], Waliszewska A, Tandon A, Lincoln RR, DeLoa C, Fruhan SA, Cabre P, et al.: A whole- 
genome admixture scan finds a candidate locus for multiple sclerosis susceptibility. Nat Genet 2005, 37(10): I I I3- I I I8.

8. Villoslada P, Hauser SL, Bartke I, Unger J, Heald N, Rosenberg D, Cheung SW, Mobley WC, Fisher S, Genain CP: Human nerve growth factor protects common marmosets against autoimmune encephalomyelitis by switching the balance of $T$ helper cell type $I$ and 2 cytokines within the central nervous system. J Exp Med 2000, I91(10): I799-1806.

9. Capsoni S, Giannotta S, Cattaneo A: Nerve growth factor and galantamine ameliorate early signs of neurodegeneration in anti-nerve growth factor mice. Proc Natl Acad Sci USA 2002, 99(19): 12432-12437.

10. Akkad DA, Jagiello P, Szyld P, Goedde R, Wieczorek S, Gross WL, Epplen JT: Promoter polymorphism rs3087456 in the MHC class II transactivator gene is not associated with susceptibility for selected autoimmune diseases in German patient groups. Int J Immunogenet 2006, 33(I):59-6I.

II. Erdfeld E, Faul F, Buchner A: GPOWER: A general power analysis program. Behaviour Research Methods, Instruments, \& Computers |996, 28: I-II.

12. Flugel A, Matsumuro K, Neumann H, Klinkert WE, Birnbacher R, Lassmann $\mathrm{H}$, Otten $\mathrm{U}$, Wekerle $\mathrm{H}$ : Anti-inflammatory activity of nerve growth factor in experimental autoimmune encephalomyelitis: inhibition of monocyte transendothelial migration. Eur J Immunol 200 I, 3 I(I): I I-22.

13. Lee R, Kermani P, Teng KK, Hempstead BL: Regulation of cell survival by secreted proneurotrophins. Science 200I, 294(5548): $1945-1948$.

14. Alam M, Pravica V, Fryer AA, Hawkins CP, Hutchinson IV: Novel polymorphism in the promoter region of the human nerve growth-factor gene. Int J Immunogenet 2005, 32(6):379-382.

15. Niino M, Fukazawa T, Yabe I, Kikuchi S, Sasaki H, Tashiro K: Vitamin $D$ receptor gene polymorphism in multiple sclerosis and the association with HLA class II alleles. I Neurol Sci 2000, |77(1):65-7|.

16. Pedersen LB, Nashold FE, Spach KM, Hayes CE: I,25-dihydroxyvitamin D3 reverses experimental autoimmune encephalomyelitis by inhibiting chemokine synthesis and monocyte trafficking. I Neurosci Res 2007, 85( I I ):2480-2490.

17. Martocchia A, Sigala S, Proietti A, D'Urso R, Spano PF, Missale C Falaschi $P$ : Sex-related variations in serum nerve growth factor concentration in humans. Neuropeptides 2002, 36(6):39|-395.

\section{Pre-publication history}

The pre-publication history for this paper can be accessed here:

http://www.biomedcentral.com/1471-2350/9/107/pre

pub
Publish with Bio Med Central and every scientist can read your work free of charge

"BioMed Central will be the most significant development for disseminating the results of biomedical research in our lifetime. "

Sir Paul Nurse, Cancer Research UK

Your research papers will be:

- available free of charge to the entire biomedical community

- peer reviewed and published immediately upon acceptance

- cited in PubMed and archived on PubMed Central

- yours - you keep the copyright
BioMedcentral 